\title{
Peningkatan Pemahaman Akuntansi Berdasarkan SAK EMKM Pada Koperasi UKM Tajur Halang Makmur Bogor
}

\author{
https://doi.org/10.32509/abdimoestopo.v4i02.1455
}

\author{
Suhartono $^{1 *}$, Hasanudin ${ }^{2}$, Ninuk Riestiningtyas ${ }^{3}$, Abdurrachaman $^{4}$, Ersa Ramadhinny $^{5}$ \\ Fakultas Ekonomi dan Bisnis, Universitas Bina Sarana Informatika \\ Jl. Kramat Raya No. 98 Jakarta - Indonesia \\ *Email Korespondensi: suhartono.sht@bsi.ac.id
}

\begin{abstract}
$\overline{\text { Abstract - SMEs as one of the driving wheels of the nation's economy have an important role in the }}$ current millennial era. There is a lot of government support for the survival and progress of SMEs in Indonesia. Starting from government social assistance to increase SME capital to providing incentives. One of them is the tax incentive provided by the government to SMEs that have financial reports based on SAK EMKM. Not many SMEs have financial reports in their business activities, especially those that are appropriate and based on SAK EMKM. The purpose of this community service activity is to increase the understanding of accounting for members of the Tajur Halang Cooperative, Bogor. The method used in this service is the SWOT (Strength, Weakness, Opportunity and Threat) analysis method. There are several stages used in this service, namely; preparation stage, implementation stage and evaluation stage. The preparation stage is to determine the theme, prepare the required equipment/equipment in the form of modules, LCD projectors and those needed in the field. The implementation phase includes surveys, observations and interviews of partner needs. Evaluation stage by giving questionnaires and tests at the beginning and at the end of the activity. The results of this service show that there is a significant increase in accounting understanding in participants' knowledge and understanding of making financial reports according to SAK EMKM. One of the benefits is that it makes it easier for SMEs to get capital from banks.
\end{abstract}

Keywords: Accounting, increasing understanding, SAK EMKM

\begin{abstract}
Abstrak - UKM sebagai salah satu roda penggerak ekonomi bangsa mempunyai peranan yang penting di era milenial saat ini. Sangat banyak dukungan pemerintah terhadap kelangsungan hidup dan kemajuan UKM di Indonesia. Mulai dari bantuan sosial pemerintah untuk menambah permodalan UKM sampai pemberian insentif. Salah satunya adalah insentif pajak yang diberikan pemerintah kepada UKM yang mempunyai laporan keuangan berdasarkan SAK EMKM. Tidak banyak UKM yang mempunyai laporan keuangan dalam kegiatan usahanya, apalagi yang sesuai dan berdasarkan SAK EMKM. Tujuan kegiatan pengabdian kepada masyarakat ini adalah untuk meningkatkan pemahaman akuntansi bagi anggota Koperasi UKM Tajur Halang Bogor. Metode yang digunakan dalam pengabdian ini adalah metode analisis SWOT (Strenght,Weakness,Opportunity dan Threat). Ada beberapa tahap yang digunakan dalam pengabdian ini, yaitu ; tahap persiapan, tahap pelaksanaan dan tahap evaluasi. Tahap persiapan yaitu menentukan tema, menyiapkan perlengakapan/peralatan yang dibutuhkan baik berupa modul, LCD proyektor dan yang dibutuhkan dilapangan. Tahap pelaksanaan meliputi survey, obeservasi dan wawancara terhadap kebutuhan mitra. Tahap evaluasi dengan memberikan kuesioner dan tes di awal dan di akhir kegiatan. Hasil dari pengabdian ini menunujukkan bahwa terjadi peningkatan pemahaman akuntansi yang signifikan pada pengetahuan dan pemahaman peserta tentang pembuatan laporan keuangan sesuai SAK EMKM. Salah satu manfaatnya yaitu mempermudah UKM untuk mendapatkan permodalan dari perbankan.
\end{abstract}

Kata Kunci: Akuntansi, peningkatan pemahaman, SAK EMKM 


\section{PENDAHULUAN}

Koperasi merupakan salah satu wadah masyarakat yang bertujuan untuk mewujudkan kesejahteraan anggotanya dan masyarakat sekitarnya. Keberhasilan koperasi terletak pada peran anggotanya sebagai pemilik dan penguna jasa koperasi. Semakin besar partisipasi anggota terhadap produk/jasa koperasi, semakin meningkat juga pendapatan dan kesejahteraan anggota koperasi. Penelitian (Yusuf et al., 2014) membuktikan bahwa 80\% koperasi sangat membantu anggotanya dalam penyediaan kebutuhan sehingga meningkatkan pendapatan anggota.

Selain itu, akuntansi juga mempunyai peranan yang sangat penting dalam mencapai tujuan koperasi melalui penyajian laporan keuangan berdasarkan SAK EMKM yang benar (B. N. Pertiwi et al., 2020). Diperlukan pemahaman akuntansi yang baik dan benar agar laporan keuangan yang dihasilkan sesuai dengan standar keuangan. Berikut ini beberapa penelitian terdahulu terkait pemahaman akuntansi seperti penelitian yang telah dilakukan oleh (Irwansyah, 2013), yang mengemukakan bahwa pemahaman akuntansi di dorong oleh faktor minat akuntansi yang baik. Penelitian (Nelson et al., 2008), kemampuan dasar akuntansi yang dimiliki oleh seseorang mempengaruhi pemahaman akuntansi yang dimilikinya. Kemudian penelitian (Yang et al., 2012) (Uyar \& Güngörmüş, 2011) (Stenberg et al., 2010), kemampuan berhitung sangat menunjang pemahaman akuntansi. Penelitian (McCarthy, 2010) (Lizzio et al., 2002) (Kazu, 2009) (Accountants, 2001) (Harrison et al., 2006), semua gaya belajar dapat membantu sukses seseorang dalam pemahaman akuntansi. Penelitian (Malgwi, 2002), pemahaman akuntansi melalui beberapa level tahapan belajar. Peneltian Satyasa dalam (Listiyani \& Widayati, 2012) mengemukakan bahwa salah tafsir, tidak fokus dan tidak terjadinya pemahaman merupakan faktor yang sering terjadi dalam proses pembelajaran. Kemudian penelitian (Lim \& Morris, 2009), pengalaman belajar yang berkesinambungan mempengaruhi pemahaman akuntansi.

Masalah yang terjadi pada Koperasi UKM Tajur Halang Makmur salah satunya yang sangat penting yaitu dalam pembuatan laporan keuangannya belum berdasarkan SAK EMKM. Yang dimaksud dengan SAK EMKM yaitu standar akuntansi keuangan yang diterbitkan oleh IAI bagi entitas mikro, kecil, dan menengah untuk akuntabilitas dan pengambilan keputusan (Putra, 2018) (Pratiwi, 2018) (Sholikin \& Setiawan, 2018) (Rachmanti et al., 2019). Salah satu manfaat SAK EMKM menurut (N. A. Pertiwi et al., 2020) yaitu koperasi dapat mempunyai akses yang lebih luas untuk memperoleh pinjaman dari bank. Untuk itu diperlukan peningkatan pemahaman akuntansi berdasrkan SAK EMKM bagi seluruh anggota koperasi.

Atas dasar ini maka kegiatan Pengabdian kepada Masyarakat dengan judul peningkatan pemahaman akuntansi berdasarkan SAK EMKM bagi anggota Koperasi UKM Tajur Halang Makmur Bogor di selenggrakan.

\section{METODE PELAKSANAAN}

Ada beberapa tahap yang dilakukan dalam Pengabdian Masyarakat ini yaitu panitia melakukan survey dan observasi langsung yang dilakukan oleh perwakilan kelompok karena masih dalam masa pandemi untuk mencari obyek atau tempat pengabdian masyarakat. Setelah didapatkan peserta pengabdian masyarakat, panitia melakukan wawancara dengan Ketua Koperasi dan beberapa anggota koperasi untuk mengetahui kebutuhan dan permasalahan utama untuk dicarikan solusinya bersama. Dalam tahap ini, diketahui bahwa masalah utamanya adalah masih banyak anggota koperasi UKM Tajur Halang yang belum mendapatkan akses langsung ke perbankan karena laporan keuangannya belum berdasarkan SAK EMKM. Hampir semua anggota koperasi UKM mengalami kesulitan dalam pembukuan transaksi dan aset-asetnya. Setelah diketahui inti permasalahan utamanya yaitu kurangnya pemahaman akuntansi anggota koperasi UKM dalam pembukuan transaksi dan penyusunan laporan keuangan, panitia pengabdian masyarakat yang mayoritas latar belakang pendidikannya adalah akuntan, sangat 
memahami permasalahan tersebut sehingga perlu dilakukan peningkatan pemahaman akuntansi bagi semua anggota koperasi dalam pembuatan laporan keuangan berdasarkan SAK EMKM.

Panitia membuat membuat modul/media pembelajaran untuk memudahkan peserta memahami materi yang akan diberikan dengan menelusuri berbagai literatur dari berbagai sumber untuk mendapatkan referensi materi terupdate terkait dengan pengabdian masyarakat ini. Saat pelaksanaan pengabdian masyarakat, panitia memberikan ceramah serta latihan studi kasus dengan media pembelajaran yang tersedia oleh perwakilan kelompok dan online learning yang difasilitasi dengan Zoom Meeting dikarenakan kondisi Pandemi Covid-19 yang masih diberlakukannya Pemberlakukan Pembatasan Kegiatan Masyaraka (PPKM) di wilayah Jabodetabek. Panitia juga melakukan diskusi dan tanya jawab saat dan setelah penyajian presentasi materi dan memberikan solusi terhadap permasalahan yang ditanyakan peserta.

Diakhir kegiatan, pantia melakukan evaluasi kegiatan untuk mengetahui tingkat pengetahuan dan pemahaman peserta dengan memberikan kuesioner dan tes pemahaman akuntansi sebelum dan setelah kegiatan berlangsung.

\section{HASIL DAN PEMBAHASAN}

Kegiatan Pengabdian kepada Masyarakat ini dilakukan pada tanggal 13 Maret 2021 pada Koperasi UKM Tajurhalang Makmur Bogor yang beralamat di Ruko Ning's Residence, Jalan Raya Kalisuren, Kelurahan Kalisuren, Kecamatan Tanjung halang, Kabupaten Bogor. Pendirian koperasi telah ditetapkan dengan akta pendirian No. 04 tanggal 3 September 2019.

Dengan visi mewujudkan koperasi dan UMKM yang kuat, tangguh dan berdaya saing menuju kemandirian, keadilan dan kesejahteraan anggota serta masyarakat. Koperasi UKM Tajurhalang Makmur berusaha untuk terus meningkatkan kualitas, peran koperasi dan UMKM dalam rangka memacu pertumbuhan ekonomi anggota dan masyarakat.

Dalam hal keanggotaannya Koperasi UKM Tanjunghalang terdiri dari anggota Forum UMKM Kecamatan Tajurhalang Makmur serta masyarakat sekitar yang berdomisili di Kabupaten Bogor. Sampai dengan Oktober 2020, anggota Koperasi UKM Tajurhalang Makmur sudah mencapai 42 orang yang semakin besar memiliki usaha menengah kecil di bidang kuliner, souvenir dan catering.

Hasil survey yang dilakukan melalui observasi dan wawancara terhadap ketua dan anggota koperasi UKM Tajur Halang menunjukkan bahwa masalah utama anggota koperasi adalah adalah kesulitan dalam permodalan terutama saat pengajuan kredit di Lembaga keuangan yang mengharuskan UKM memiliki laporankeuangan berdasarkanSAK EMKM. Kemampuan UKM dalammengelola administrasi keuangan dan manajemen yang baik juga masih kurang sehingga diperlukan pelatihan terkait pembuatan LaporanKeuangan yang sesuai StandarAkuntansi KeuanganEntitasMikro, Kecildan Menengah(SAKEMKM)

Adapunlangkah-langkah yangharus dilakukan setiap peserta UKM, yaitu mempersiapkan contoh bukti - bukti transaksi yang berhubungan dengan transaksi bisnis UKM, mencatat transaksi berdasarkan bukti-bukti transaksi yang ada dan mengkategorikan kedalam Buku Besar Utama dan Buku Besar Pembantu, membuat buku-buku pencatatan melalui kertas kerja yang sudah disiapkan, membuat penyesuaian terhadap saldo-saldo akun untuk menyesuaiakan saldo-saldo menjadi seharusnya, membuat Laporan Keuangan sederhana sesuai kertas kerja yang sudah disiapkan. Kemudain menyajikan laporan keuangan sederhana tersebut dalam format yang sudah disesuaikan berdasarkan SAK EMKM yang berlaku.

Ke enam langkah tersebut dilakukan saat pelatihan peningkatan pemahaman akuntansi dan pemahaman peserta lebih ditingkatkan lagi dengan ditambahkannya sesi diskusi baik saat presentasi berlangsung atau setelah presentasi selesai diberikan. Saat presentasi materi diberikan, peserta dapat menanyakan langsung ke penyaji jika ada materi yang belum dipahami. Demikian juga setelah presentasi selesai disajikan, peserta dapat menanyakan baik materi yang 
telah diberikan atau tentang kendala yang sedang dihadapi peserta dalam penyajian laporan keuangan.

Materi yang diberikan membahas tentang penyusunan laporan keuangan berdasarkan SAK EMKM meliputi unsur-unsur aset, liabilitas, ekuitas yang berdasarkan biaya historis/biaya perolehan sebesar jumlah kas atau setara kas yang dibayarkan untuk memperolehnya. Laporan keuangan yang dihasilkan minimal terdiri dari laporan posisi keuangan UKM di akhir periode yang meliputi : kas dan setara kas, piutang, persediaan, aset tetap, utang usaha, utang bank dan ekuitas, laporan laba rugi UKM selama periode, meliputi : pendapatan, beban keuangan dan beban pajak dan catatan atas laporan keuangan yang meliputi : pernyataan telah disusun berdasarkan SAK EMKM, ikhtisar kebijakan akuntansi, informasi tambahan dan rincian pos tertentu.

Saat sesi diskusi banyak pertanyaan-pertanyaan yang diberikan kepada penyaji mengenai teknis dasar pembuatan laporan keuangan dan kendala yang dihadapi peserta saat penyusunannya. Peserta sangat antusias dengan materi yang diberikan dan kesempatan tanya jawab digunakan dengan semaksimal mungkin.

Pada saat pelatihan pserta dapat berpartisipasi aktif dalam mengkategorikan bukti transaksi, memasukkan kedalam buku besar, membuat penyesuaian dan laporan keuangan pada kertas kerja sesuai studi kasus yang dibuat sedemikian rupa sehingga dapat dipahami oleh peserta pelatihan.

Dapat terlihat bahwa kegiatan pengabdian masyarakat ini berjalan dengan baik dan lancar dari respon peserta dan partisipasi aktif peserta saat diskusi dan pelatihan.

Setelah kegiatan pengabdian masyarakat selesai dilakukan, tahap terakhir yaitu dilakukan evaluasi kegiatan dengan memberikan kuesioner kepada peserta. Kuesioner berupa pertanyaan tertutup yang diberikan kepada semua peserta UKM sebelum dan sesudah pelatihan untuk mengetahui sejauh mana manfaat kegiatan pengabdian masyarakat terutama dalam hal peningkatan pemahaman akuntansi peserta. Secara keseluruhan hasil dari kegiatan pengabdian masyarakat sangat memuaskan dan meningkatkan pemahaman akuntansi peserta.

Manfaat dilaksanakannya pengabdian masyarakat di Koperasi UMKM Tajuar Halang Bogor peserta menjadi bertambah wawasan dan pengetahuannya dan dapat memahami pembuatan buku besar dan neraca saldo berdasarkan SAK EMKM dengan baik, sehingga dapat memudahkan pekerjaan dalam pembuatan laporan keuangan dan pendanaan dalam kebutuhan operasionalnya. Pihak Koperasi UMKM Tajuar Halang Bogor sangat kooperatif dalam pelaksanaan pengabdian masyarakat dan menyambut dengan antusias kegiatan ini.

Berikut ini adalah hasil persentase responden yang menjawab semua pertanyaan dalam bentuk diagram lingkaran.

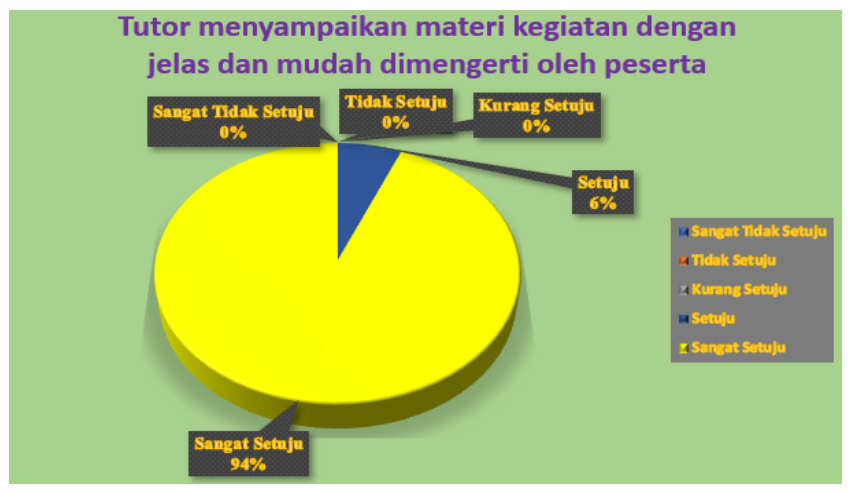

Gambar 1 : Persentase penyampaian materi (Sumber: Dokumentasi Peneliti)

Persentase penyampaian materi oleh tutor sangat jelas dan mudah dimengerti oleh peserta UKM Tajur Halang yaitu sebesar 94\% sangat setuju, sedangkan sisanya 6\% setuju. 


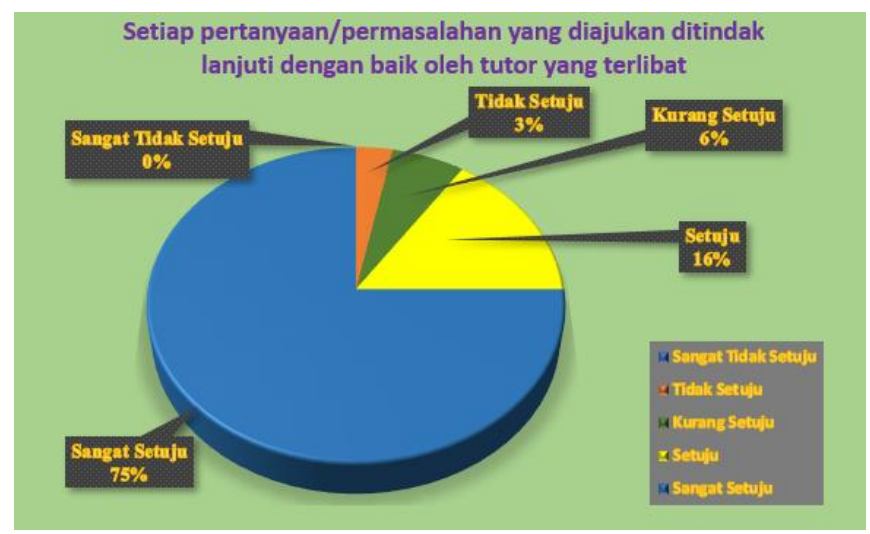

Gambar 2 : Persentase pertanyaan/permasalahan (Sumber: Dokumentasi Peneliti)

Persentase pertanyaan/permasalahan yang ditindak lanjuti oleh tutor yaitu sebesar $75 \%$ sangat setuju,sedangkan sisanya16\% setuju, $6 \%$ kurangsetuju dan $3 \%$ tidaksetuju

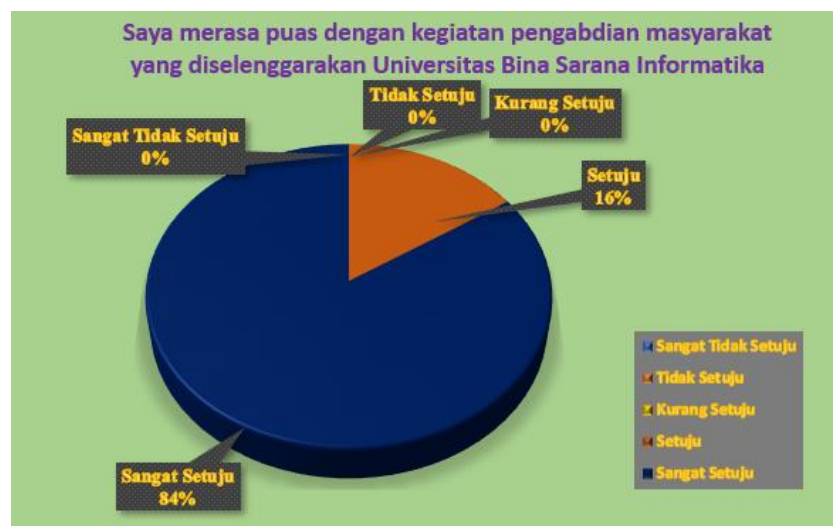

Gambar 3 : Persentase kepuasan peserta (Sumber: Dokumentasi Peneliti)

Persentase kepuasan peserta terhadap kegiatan pengabdian kepada masyarakat yaitu sebesar $84 \%$ sangat setuju, sedangkan sisanya $16 \%$ setuju.

Berikut ini hasil analisis perbandingan pengetahuan dan pemahaman akuntansi peserta pada sebelum dan sesudah mengikuti kegiatan pengabdian kepada masyarakat. Pada tabel 1 dibawah ini terlihat bahwa tingkat pemahaman akuntansi anggota koperasi UKM Tajur Halang Bogor mengalami peningkatan yang sangat berarti dimana nilai rata-rata pemahamaan akuntansi sebelum kegaiatan yaitu 39 meningkat menjadi 85 .

Tabel 1. Tingkat pemahaman akuntansi

\begin{tabular}{|c|c|c|c|c|c|}
\hline \multicolumn{2}{|r|}{ Nama Mitra } & \multicolumn{4}{|c|}{ : Koperasi UKM Tajur Halang Bogor } \\
\hline \multicolumn{2}{|r|}{ Tanggal Kegiatan } & \multicolumn{4}{|c|}{ : 13 Maret 2021} \\
\hline \multirow{2}{*}{ No. } & \multicolumn{3}{|c|}{ Data Responden } & \multicolumn{2}{|c|}{ Score Nilai : } \\
\hline & Nama Responden & $\mathrm{L} / \mathrm{P}$ & Umur & Sebelum & Sesudah \\
\hline 1 & Kaspul Anwar & $\mathrm{L}$ & $>50$ & 40 & 85 \\
\hline 2 & Berlian Siahaan & $\mathrm{P}$ & $>50$ & 35 & 80 \\
\hline 3 & Mulyadi & $\mathrm{L}$ & $46-50$ & 45 & 80 \\
\hline
\end{tabular}




\begin{tabular}{|c|c|c|c|c|c|}
\hline 4 & Euis Kastuti & $\mathrm{P}$ & $>50$ & 30 & 90 \\
\hline 5 & Maisaroh & $\mathrm{P}$ & $46-50$ & 40 & 80 \\
\hline 6 & Asmaniar & $\mathrm{P}$ & $36-40$ & 30 & 80 \\
\hline 7 & Herawati & $\mathrm{P}$ & $46-50$ & 30 & 80 \\
\hline 8 & Nanan Herlina & $\mathrm{P}$ & $31-35$ & 30 & 80 \\
\hline 9 & Santi & $\mathrm{P}$ & $46-50$ & 30 & 85 \\
\hline 10 & Yunita Tresiana & $\mathrm{P}$ & $46-50$ & 35 & 75 \\
\hline 11 & Mirawati & $\mathrm{P}$ & $46-50$ & 45 & 90 \\
\hline 12 & Tridayawati & $\mathrm{P}$ & $>50$ & 40 & 90 \\
\hline 13 & Iah Mudiah & $\mathrm{P}$ & $46-50$ & 40 & 90 \\
\hline 14 & Rustaria Simanjuntak & $\mathrm{P}$ & $<30$ & 40 & 85 \\
\hline 15 & Tuti Purwasih & $\mathrm{P}$ & $31-35$ & 50 & 80 \\
\hline 16 & Laksmita Andalusiana & $\mathrm{P}$ & $36-40$ & 45 & 90 \\
\hline 17 & Fible Krisdiansari & $\mathrm{P}$ & $41-45$ & 50 & 90 \\
\hline 18 & Rusinah & $\mathrm{P}$ & $46-50$ & 30 & 90 \\
\hline 19 & Sri Pujiati & $\mathrm{P}$ & $46-50$ & 35 & 75 \\
\hline 20 & Kisah & $\mathrm{P}$ & $>50$ & 40 & 90 \\
\hline 21 & Dwi Retno Susanti H. & $\mathrm{P}$ & $>50$ & 40 & 85 \\
\hline 22 & Lili Rahayu & $\mathrm{P}$ & $46-50$ & 30 & 90 \\
\hline 23 & Deddi Sanjaya & $\mathrm{L}$ & $36-40$ & 30 & 85 \\
\hline 24 & Julkaryana Putra & $\mathrm{L}$ & $36-40$ & 30 & 90 \\
\hline 25 & Edah Zubaedah & $\mathrm{P}$ & $36-40$ & 45 & 75 \\
\hline 26 & Setiyanah & $\mathrm{P}$ & $>50$ & 40 & 90 \\
\hline 27 & Yanti/Siti Nur Apriya & $\mathrm{P}$ & $36-40$ & 40 & 90 \\
\hline 28 & Erlangga & $\mathrm{L}$ & $31-35$ & 40 & 85 \\
\hline 29 & Nurdini & $\mathrm{P}$ & $36-40$ & 40 & 90 \\
\hline 30 & Linda Lestari & $\mathrm{P}$ & $31-35$ & 50 & 80 \\
\hline 31 & Dra. Ulfah Nuriah M. & $\mathrm{P}$ & $>50$ & 35 & 90 \\
\hline 32 & Rani Juliartini & $\mathrm{P}$ & $41-45$ & 40 & 85 \\
\hline
\end{tabular}




\section{SIMPULAN}

Hasil dari kuesioner yang telah diberikan pada akhir kegiatan diketahui bahwa peserta sangat puas terhadap penyampaian materi yang diberikan oleh tutor baik secara teori dan praktiknya langsung dengan studi kasus, solusi dan jawaban yang diberikan tutor terhadap semua pertanyaan/permaslahan yang diajukan peserta dan seluruh rangkaian kegiatan pengabdian masyarakat yang telah dilakukan.

Hasil dari tes pemahaman akuntansi sebelum dan sesudah kegiatan berlangsung menunjukkan bahwa telah terjadi peningkatan pemahaman akuntansi peserta UKM Tajur Halang terhadap pembuatan/penyajian laporankeuangan yang sesuai dan berdasarkan SAKEMKM sehingga dapat dihasilkan laporankeuangan yang akuntabiltas dan memudahkan peserta UKM dalam pengajuan modal ke bank.

\section{Ucapan Terima Kasih}

Ucapan terima kasih kami sampaikan kepada Ketua Koperasi Tajur Halang Bogor yang telah memberikan kesempatan untuk menyelenggarakan kegiatan pengabdian kepada masyarat ini. Tidak lupa juga kami sampaikan ucapan terima kasih kepada Pimpinan Unversitas Bina Sarana Informatika dan seluruh pihak yang telah mendukung kegiatan Pengabdian Kepada Masyarakat ini sebagai salah satu wujud Tri Dharma Perguruan Tinggi.

\section{Daftar Pustaka}

Accountants, I. F. of. (2001). Competence-Based Approaches to the Preparation and Work of Professional Accountants.

Harrison, D., McPeak, D., \& Greenberg, S. (2006). Validating Competencies Underlying A Professional Accounting Credential. ABER 3rd Global Conference on Business and Economics,.

Irwansyah, M. R. (2013). Pengaruh Hasil Belajar Dasar-Dasar Akuntansi, Matematika Ekonomi Dan Bisnis Dan Minat Terhadap Pemahaman Akuntansi Yang Dikategorikan Berdasarkan Gaya Belajar. IKA, 11(2), 58-72.

Kazu, I. Y. (2009). The Effect of Learning Style on Education and The Teaching Process. Journa of Social Sciences. Journal of Social Sciences, 5(2), 85-94.

Lim, D. H., \& Morris, M. L. (2009). Learner and instructional factors influencing learning outcomes within a blended learning environment. Journal of Educational Technology \& Society, 12(4), 282-293.

Listiyani, I. M., \& Widayati, A. (2012). Pengembangan Komik Sebagai Media Pembelajaran Akuntansi Pada Kompetensi Dasar Persamaan Dasar Akuntansi Untuk Siswa SMA Kelas XI. Jurnal Pendidikan Akuntansi Indonesia, 10(2), 80-94.

Lizzio, A., Wilson, K., \& Simons, R. (2002). University Student's Perception of The Learning Environment and Academic Outcames : Impications for Theory and Practice. Studies in Higher Educations, 27(1), 27-52.

Malgwi, C. A. (2002). Determinants of Accounting Anxiety in Business Students. . Journal of College Teaching and Learning, 1(2), 81-94.

McCarthy, M. (2010). Experiental Learning Theory: From Theory to Practice. Journal of Business \& Economics Research., 8(5), 131-140.

Nelson, I. ., Vendrzyk, V. P., Quirin, J. J., \& KovaR, S. . (2008). Trends in Accounting Student Characteristics: Results from a 15-year Longitudinal study at FSA schools. Issues in Accounting Education, 23(3), 373-389.

Pertiwi, B. N., Yahya, M., \& Syachbrani, W. (2020). Tinjauan Penyajian Laporan Keuangan Berdasarkan SAK-EMKM pada Koperasi Pegawai Dinas Koperasi Provinsi Sulawesi Selatan. BIJAC: Bata Ilyas Journal of Accounting, 1(1), 54-64. 
Pertiwi, N. A., Rohendi, H., \& Setiawan. (2020). Penyusunan Model Laporan Keuangan Entitas Mikro Kecil Menengah Berdasarkan Sak Emkm Pada Emkm Konveksi. Jurnal Accounting Information System, 3(1), 36-50.

Pratiwi, C. H. (2018). Penerapan Akuntansi Persediaan Berbasis SAK EMKM Pada UD Andika Jaya Jember. Journal of Economic, Business and Accounting (COSTING), 2(1), 118-124.

Putra, Y. M. (2018). Pemetaan Penerapan Standar Akuntansi Keuangan Emkm Pada UMKM di Kota Tangerang Selatan. Profita: Komunikasi Ilmiah Akuntansi Dan Perpajakan, 11(2), 201-216.

Rachmanti, D. A. A., Hariyadi, M., \& Andrianto. (2019). Analisis Penyusunan Laporan Keuangan UMKM Batik Jumput Dahlia Berdasarkan SAK-EMKM. Balance, 14(1), 3152.

Sholikin, A., \& Setiawan, A. (2018). Kesiapan UMKM Terhadap Implementasi SAK EMKM (Studi UMKM Di Kabupaten Blora. Journal of Islamic Finance and Accounting, 1(2), 3650 .

Stenberg, L., Varua, M. E., \& Yong, J. (2010). Mathematics Aptitude, Attitude, Secondary Schools and Student Success in Quantitative Methods for Business Subject in an Australian Catholic University Experience. The Annual Confrence Economist, 1-6.

Uyar, A., \& Güngörmüş, A. H. (2011). Factors Associated with Student Performance in Financial Accounting Course. European Journal of Economic and Political Studies, 4(2), 139-154.

Yang, F., Mo, L., \& Dolar, B. (2012). Early Career Interest Development in Accounting: The Effect of Race after Controlling Math Performance and Gender. Journal of Accounting and Finance Research, 1(2), 59-65.

Yusuf, D., Amiluddin, \& Jumraini. (2014). Peranan Koperasi Sebagai Penyedia Kebutuhan Nelayan di Kabupaten Barru. Jurnal IPTEKS PSP, 1(2), 174-184. 